УДК 616.131-005.6/7+616.1(062)

https://doi.org/10.30702/card:sp.2019.10.038/0342843

Батушкін В. В. ${ }^{1}$, Кузьменко В. В. ${ }^{2}$, Дакалов Д. С. ${ }^{2}$

${ }^{1}$ ВПНЗ «Київський медичний університет», м. Київ, Україна

${ }^{2}$ Київська міська клінічна лікарня № 5, м. Київ, Україна

૧૯Batushkin V. V. ${ }^{1}$, Kuzmenko V. V. ${ }^{2}$, Dakalov D. S. ${ }^{2}$

${ }^{1}$ Kyiv Medical University, Kyiv, Ukraine

${ }^{2}$ Kyiv City Clinical Hospital No. 5, Kyiv, Ukraine

\title{
$\square$ Gastrointestinal Bleeding and Other Types of Bleeding in Patients Receiving Long-Term Anticoagulation. Oral Anticoagulants Safety Assessment and Bleeding Treatment Algorithms
}

Abstract. We analyzed hospitalization and treatment of patients with acute gastrointestinal bleeding (GI bleed) due to the use of antithrombotic drugs in Kyiv. For this purpose, 610 case histories of 
patients with GI bleeds who were treated at the City Center of Gastrointestinal Bleeding Emergency Surgery (Kyiv City Clinical Hospital No. 12) in 2017 were selected. Among these, antithrombotic drugs were reported as a cause of bleeding in 80 (13.1\%) patients.

According to our data, GI bleed due to acetylsalicylic acid (ASA) was the most frequent reason for hospitalization ( $71.6 \%$ of patients). GI bleed due to the use of another antiplatelet drug, clopidogrel, was reported in $5 \%$ of patients. In half of them, bleeding required packed RBC transfusion. One patient died. The combination of clopidogrel and ASA 1.5 times more often led to the development of Gl bleed than clopidogrel monotherapy. Acute bleeding was observed in $7.3 \%$ of the patients receiving this combination, and in half of them, bleeding was life-threatening.

Due to the severity of GI bleed, every second patient with GI bleed caused by the intake of clopidogrel or clopidogrel with ASA required packed RBC transfusion, compared to only $15.5 \%$ of those with GI bleed caused by ASA. Our meta-analysis of the safety of disaggregants emphasizes a 2.4-fold increase in the bleeding risk when switching patients from ASA $75 \mathrm{mg}$ monotherapy to clopidogrel $75 \mathrm{mg}$. In our study, warfarin-dependent Gl bleeds were somewhat less common than those caused by the use of antiplatelet drugs and accounted for $10 \%$ of patients, but half of these Gl bleeds were critical. Oral anticoagulants (OACs) in our analysis caused Gl bleed in $3.7 \%$ of cases. It was rivaroxaban or rivaroxaban combined with ASA. Interestingly, age and gender were not critical to the incidence of bleeding. In $33.3 \%$ of patients, bleeding was critical. 
There are different classifications of bleeding, however, the main types include fatal bleeding, bleeding requiring hospital admission, bleeding requiring blood transfusion (single-unit, double-unit), or bleeding in critical areas (eg, intracranial, retroperitoneal, intraspinal, intraocular, pericardial). In each of the main clinical trials of OACs, the incidence of intracranial hemorrhage was significantly lower than that for warfarin. Although OACs have recognized advantages over warfarin, patients with atrial fibrillation who take these drugs for anticoagulation are still at risk of future bleeding. To date, no specific antidote is available to reverse OACs other than dabigatran. Other strategies for stopping anticoagulant effects of OACs are limited. Regardless of the choice of anticoagulant used for GI bleed prevention, long-term evaluation of drug therapy is critical to ensure that bleeding events are monitored and minimized, including blood pressure regulation, kidney function monitoring, and concomitant medications use.

Keywords: anticoagulant therapy in different patient categories, oral anticoagulants, warfarin, gastrointestinal bleeding and other hemorrhagic complications, treatment and prevention.

Резюме. Ми проаналізували госпіталізацію і лікування хворих 3 гострими шлунково-кишковими кровотечами (ШКК) внаслідок застосування антитромботичних препаратів у м. Києві. Для цього було відібрано 610 історій хвороб пацієнтів із ШКК, пролікованих у Міському центрі невідкладної хірургії шлунково-кишкових кровотеч (Київська міська клінічна лікарня № 12) за 2017 рік. Серед них антитромботичні препарати як джерело кровотечі були відзначені у $80(13,1 \%)$ хворих. 
За нашими даними, ацетилсаліцилова кислота (АСК) була найчастішою причиною госпіталізації внаслідок ШКК - у 71,6 \% хворих. Розвиток ШКК у зв'язку з використанням іншого антитромбоцитарного препарату - клопідогрелю - визначався у 5 \% осіб. У половини з них кровотеча вимагала введення еритроцитарної маси. Один хворий помер. Комбінація клопідогрелю з АСК в 1,5 раза частіше призводила до розвитку ШКК, ніж монотерапія клопідогрелем. Гостра кровотеча спостерігалася в 7,3 \% осіб, яким призначали таку комбінацію, половина з них мала життєзагрожуючий характер кровотечі.

З огляду на тяжкість ШКК, використання еритроцитарної маси під час лікування ШКК у зв'язку з прийманням клопідогрелю або клопідогрелю з АСК потрібне було кожному другому пацієнтові, у групі АСК - тільки 15,5 \%. Наш метааналіз за безпечністю дезагрегантів наголошує на підвищенні ризику кровотеч у 2,4 раза при переведенні хворих з монотерапії АСК 75 мг на клопідогрель 75 мг. Варфрарин-залежні ШКК у нашому дослідженні спостерігалися дещо рідше, ніж унаслідок вживання антитромбоцитарних препаратів - у 10 \% хворих, однак у половини з них мали критичний характер. Пероральні антикоагулянти в нашому аналізі були причиною ШКК в 3,7 \% випадках. Це був ривароксабан або його комбінація з АСК. Цікаво, що вік і стать не мали вирішального значення для частоти розвитку кровотечі. У 33,3 \% хворих кровотеча була критичною. 
$€$ різні класифікації основних кровотеч, але зазвичай вони включають кровотечу, що призводить до смерті, госпіталізації, переливання крові, що вимагає двох або більше одиниць, або кровотечі в критичних місцях (наприклад, внутрішньочерепна, ретроперитонеальна, інтраспінальна, внутрішньоочна, перикардіальна). У кожному з основних клінічних випробувань пероральних антикоагулянтів (ПАК) частота внутрішньочерепних кровотеч була достовірно меншою порівняно з варфарином. Хоча ПАК мають визнані переваги над варфрарином, пацієнти 3 фрібриляцією передсердь, які приймають ці препарати для антикоагуляції, все ще перебувають під ризиком кровотеч. На сьогодні не існує специфічного антидоту, доступного для усунення дії будь-якого з ПАК, крім дабігатрану. Інші стратегії для зупинки антикоагулянтних ефректів ПАК обмежені. Незалежно від вибору антикоагулянту, що використовують для профрілактики ШКК, довгострокове оцінювання медикаментозної терапії має вирішальне значення для забезпечення дотримання та мінімізації подій кровотечі, включаючи регуляцію артеріального тиску, моніторинг фрункції нирок і супутнє застосування ліків.

Ключові слова: антикоагулянтна терапія в різних категорій хворих, пероральні антикоагулянти, варфарин, шлунково-кишкові кровотечі та інші геморагічні ускладнення, лікування та проорілактика. 